\title{
"Illusion" in the Postcolonial Context: Translation Studies Still in Need of a Metalanguage or the Understated Lack of Ontology of Science
}

\author{
Ayşe Betül SAYIN*
}

The purpose of this article ${ }^{1}$ is to trace the recurrent metaphor of 'illusion' in translation studies. Starting with the pioneering work of Jiří Levý titled The Art of Translation (Uméni prekladu [1963]), the optical metaphors for the subject matter of studies on translation reflect an ambiguity about the ontology of translation studies. Yet, this ambiguity does not remain in the theoretical sphere and apparently, translates into the very practices of the publishers. Prefaces and critiques by publishing houses and the translators' footnotes as paratexts suggest an ever-increasing demand for translations that 'mirror' the source work. In this respect, the back translations of ethnographic works and semi-ethnographic travelogues provide fertile ground for exploring the boundaries of conceptual determinism in translation theory. After an inquiry on the shifting points of reference between translation norms and illusion, this descriptive study analyzes the Turkish translation of An Englishwoman in a Turkish Harem (1915), a semi-ethnographic work pointing to other works of dubious origin. By considering this translation that is claimed by the publishing house to have been transferred almost unmediated as a product of back translation, the present study illustrates the underlying stance of the seemingly divergent points of view on designations and metaphors for translation (i.e., illusion) in terms of translation studies as an autonomous field of 'proper' social science. Hence, this study ultimately aims to reveal that the ambiguity about the concept of translation overlooks the underlying ontology(ies) of science of translation.

Keywords: illusionistic translation; descriptive translation studies; metaphors of translation; translation studies ontology

\section{The Research Rationale}

The concept "illusion of transparency" coined by Lawrence Venuti has been widely discussed since the publication of the book titled The Translator's Invisibility: A History of Translation, which manifests a dichotomy of what is categorized as fluent and resistant translation strategies. Particularly in the context of postcolonial translation studies, this metaphor referring to a binary structure points to a taxonomic approach to the notion of

\footnotetext{
* PhDc at Istanbul 29 Mayis University.

E-mail: ayse.b.sayin@gmail.com; ORCID ID: https://orcid.org/0000-0002-8251-697X.

(Received 8 July 2019; accepted 21 December 2019)

${ }^{1}$ Produced from the author's master's thesis (Sayin 2019b) submitted at Istanbul 29 Mayis University under the supervision of Işın Öner.
} 
transLogos 2019 Vol 2 Issue 2

Sayın, Ayşe Betül, pp. 180-203

"Illusion" in the Postcolonial Context:

Translation Studies Still in Need of a

$\operatorname{trans}$ Logos

A Translation Studies Journal

Metalanguage or the Understated Lack of

Ontology of Science

(c) Diye Global Communications diye.com.tr|diye@diye.com.tr

translation. Interestingly enough, the double bind of translation is addressed on the theoretical level, but its presentation on the textual level remains problematic. Because of his disregard of "simply descriptive" research and related theoretical ground for contextualizing translations, Venuti positions strategies on a unilinear scale $(2004,312)$. However, as she recognizes this binarism and aims to surpass its limits, Maria Tymoczko argues for an empirical approach that is not generally associated with the progress of descriptivism in translation studies. In her comprehensive work on this subject titled Translation in a Postcolonial Context: Early Irish Literature in English Translation, Tymoczko states that the literature on postcolonial translations illustrates specific implications of paradigmatic preferences $(2014,55)$. Though adhering to 'a descriptive study of translations,' her self-refuting criticism about "acceptable" and "adequate" translations in Gideon Toury's theorizing leads her to look for metonyms for translation. Therefore, the tools of analysis Tymoczko chooses to use in order to revoke James S. Holmes's (1988) call for investigations about metametonyms for translation are familiar to a translation researcher but are grouped under rather an uncommon name, viz. "conventional translation equivalents" (CTEs). In her article titled "Translations of Themselves: The Contours of Postcolonial Fiction," Tymoczko asserts that "the use of CTEs in the target-language (TL) text gives the illusion of surface transparency" $(2000,156)$. To give a brief definition of CTEs, they are "pairings, that link or mediate common cultural concepts across existing linguistic boundaries" (153). As "specific vehicles of polyvalent writing" (149), CTEs do not simply work as equivalents with clear boundaries, rather "they import or transfer the source language (SL) meanings associated with the SL words." Here, the crucial point for the present study is that the unclear boundaries of means of analysis and the metaphor of 'illusion' highlight two underlying questions fundamental to any translation research. First question represents an hour-glass shaped problem: should research go meta or deep into the core, to the very beginning of conceptualizations regarding the subject matter of translation studies? The second question foregrounds the lack of critical inquiry behind the metaphor of illusion. Because "the presence of CTEs in a literary work suggests the existence of a pre-text in another language" (156), the effect a concealed native equivocally creates in translation is essentially an illusion. Hence, what illusion may a semi-ethnographical work 
transLogos 2019 Vol 2 Issue 2

Sayın, Ayşe Betül, pp. 180-203

"Illusion" in the Postcolonial Context:

Translation Studies Still in Need of a

trans Dogos

A Translation Studies Journal

Metalanguage or the Understated Lack of

Ontology of Science

(C) Diye Global Communications diye.com.tr|diye@diye.com.tr

translated back to its culture of 'origin' serve for the target audience, or what may be the theoretical implications of the back translation of cultural translation? ${ }^{2}$

In other words, do we need a metalanguage, a metametonym in order to combine the smaller metonyms "into larger interrelated and balanced textures" (Tymoczko 2014, 282) or explore 'das Absolut' or 'invariant' of translation studies? For this purpose, the theoretical framework of this article will follow the traces of metaphor of illusion from the predescriptive era of translation studies as a sub-branch of linguistics to the descriptivism followed by the re-emergence of humanities-inspired approaches to translation studies. Unsurprisingly, this investigation into the metaphor of illusion reveals in Theo Hermans's (2009) words: "the downgrading of equivalence is accompanied by an upgrading of the notion of norms" (54). The inquiry into how this downgrading illusion in the paratexts of postcolonial translations is created in turn poses questions central to the subject matter of translation studies. In this light, the present descriptive study analyzes the paratexts of the Turkish translation of Grace Ellison's An Englishwoman in a Turkish Harem. The divergent reception of the source text author and the framing of the work's back translation prove to be a part of an enduring understanding of what a work of translation conveys even in its 'host' cultural ground. It reveals the conception of translation and makes a careful reader ask if it is possible to think about the solid nature of the discourse of "the translated" 3 in practice. Thus, the system in which the work in question is positioned and how it can be categorized opens up stimulating paths for future research with regards to philosophy of translation studies.

\section{Illusion as a Designation for Translation}

The metaphor of illusion is originally rooted in the works of Czech structuralists, in particular Jiří Levý's The Art of Translation. Starting with the acknowledgement that significant part of translation theory is normative, Levý (2011) argues for a scientific inquiry into an art form. Because the criticism and analysis of this art form depends on establishing

\footnotetext{
${ }^{2}$ I use the concept of "cultural translation" after Clifford Geertz in the sense that putting interpretations of a culture into words is in fact a translation of culture. Though a controversial concept, it is useful for describing the two-way translation process postcolonial translations undergo. For a detailed examination of the concept and 'Writing Culture debate,' see Sturge 2007; Pratt et al. 2010; Conway 2012.

${ }^{3}$ For a thought-provoking study on how " "the translated' theories of translation" can manipulate researchers specifically in terms of naming of any kind of "textual entities" (Toury 2012, 22) in the context of intralingual translations, see Güneş 2018.
} 
transLogos 2019 Vol 2 Issue 2

Sayın, Ayşe Betül, pp. 180-203

"Illusion" in the Postcolonial Context:

Translation Studies Still in Need of a

$\operatorname{trans}$ Logos

A Translation Studies Journal

Metalanguage or the Understated Lack of

Ontology of Science

(c) Diye Global Communications diye.com.tr|diye@diye.com.tr

philosophical views on the definition of translation that remained "variable and historically conditioned" (17), Levý (1965) seeks to theorize with a method that prioritizes "a rational analysis [on translations] as opposed to subjective impressions" (quoted in Hermans 2009, 22). The argument for a rational analysis can easily make a student of translation jump to a conclusion. Yet, we should be careful about how he works his way through a certain paradigm. Here it should be marked that Levý was writing these lines about 'unscientific' approaches to translation at around the same time when Eugene Nida's book titled Towards a Science of Translating was published in 1964 and James S. Holmes (1988) uttered the term "science of translation" (70) in his 1972 manifesto paper: "The Name and Nature of Translation Studies." Though the originating line of thought can be easily distinguished from the then quite overruling linguistic and humanities-based prescriptive approaches to translation, Levý's theorizing is not completely descriptive in nature. His conception of translation as an art form is embedded in the title of his work, and his method of (pre)descriptivism rests on studying 'aesthetics of translation' based on norms (Levý 2011, 17).

A quick-witted critic that he is, Levý constructs his inquiry into "the actual procedures corresponding to this a priori established goal" called norms upon the concept of noetic compatibility $(2011,17)$. At first look a rhetorical-sounding concept, noetic compatibility is defined as a single general category that encircles special cases such as, in his own words, "[t]he aptness of the translation and the veracity of the imagery, the verisimilitude of the motivation" (19). To put it more simply, a work of translation can be assessed on the degree of its conformity to norms, its effect on the reader and its purpose. Considering noetic compatibility as the measure of a linear scale, Levý distinguishes between illusionism and anti-illusionism. Because the original semiosis of illusio is inaccessible, he explains his argument through the agents of methods, translators and works, as indicated by Zuzana Jettmarová in her foreword to The Art of Translation (Levý 2011, xxii). As simple as it seems, illusionistic methods demand "a work of literature to 'look like the original, like reality." "The translator "hide[s] behind the original" and "create[s] a translation illusion based on a contract with the reader," erasing the traces of the acts of an intermediary (19). According to Levý, readers of a translated work are already aware of the fact that they are not reading the original, 
transLogos 2019 Vol 2 Issue 2

Sayın, Ayşe Betül, pp. 180-203

"Illusion" in the Postcolonial Context:

Translation Studies Still in Need of a

trans Dogos

A Translation Studies Journal

Metalanguage or the Understated Lack of

Ontology of Science

(C) Diye Global Communications diye.com.tr|diye@diye.com.tr

but they are prepared to believe that they are reading a particular work ${ }^{4}$ and therefore, ask it "to preserve the qualities of the original" (20).

On the other hand, his conceptualization of anti-illusionistic methods is intricate and indicates a notion of translation beyond the structuralist categorizations. Anti-illusionistic methods let the work abandon the portrayal of reality and in fact, "boldly play on the fact that they are offering the audience a mere imitation of reality." Translators reveal their role as observers, comment on the text and address the reader with allusions. For Levý, parodies and travesties constitute perfect examples of anti-illusionist translations. It is striking that he clarifies his argument in positing that "[a]n abstract, athematic translation would in fact be anti-translation" because a translation first and foremost has a "representative" purpose. Moreover, illusionist translations, which are also considered "normal" translations, should be criticized in terms of "[their] values for the recipient, i.e., the distinctive or sociological functions of [their] elements" (Levý 2011, 20). Apparently, Levý distinguishes the two types of translation categories from a target-oriented perspective. Overall, it can be argued that this lumper and parallel categorization can be considered imprecise for it reduces "normal" translations to only one single definition resting on subjective criticism. However, recalling that, in order to minimize the overarching dominance of equivalence, Levý also proposed his dual norms, namely "reproduction norm" and "artistic norm" (60). The naming of the norms is a direct consequence of his definition of translation as "a borderline case at the interface between reproductive art [as a product] and original creative art [as a process]" (58). Yet, inasmuch as he attempts to free criticism from the faithful/free dichotomy, the dual norms of translation rest on the semantic and aesthetic values it conveys to the reader (61). Hence, judgment on the "beauty - artistic excellence, the aesthetic value of the translation as a work of the target national literature" (64) reverses the entire argument for a rational analysis back to where it emerged and again renews the quest for a descriptive approach to translation.

Nevertheless, by applying what Russian Formalists argued for the theory of poeticity, which can be summarized in a nutshell that poetic features of a work of art could be separated from the content and could be considered 'a formal quality' on their own, Levý's theorizing assumes an underlying concept of translation, which is implied in the inadequate relationship

\footnotetext{
${ }^{4}$ His stress on what is considered to be a translation here is limited to a literary work, and his underlying view that the reader assumes only one single interpretation of it to be available is noteworthy.
} 
transLogos 2019 Vol 2 Issue 2

Sayın, Ayşe Betül, pp. 180-203

"Illusion" in the Postcolonial Context:

Translation Studies Still in Need of a

trans Dogos

A Translation Studies Journal

Metalanguage or the Understated Lack of

Ontology of Science

(c) Diye Global Communications diye.com.tr|diye@diye.com.tr

between a sign and an object (Gentzler 2001, 84-85). For the ever-changing meaning is interpreted in two referent worlds, that of the source and that of the target, the concept of translation entails, as Edwin Gentzler puts it: "That which is made manifest in the process and product of translation is the very mobility of concepts, the mutability of signs and the evolution of the relationship between the two" (85).

How the later scholars of translation take on this notion of translation in the quest for descriptivism will reveal competing arguments for deciphering meaning in twentieth century literary theory and philosophy of language.

\section{Illusion Dethroned: Descriptive Translation Studies and - beyond}

In the revised edition of Descriptive Translation Studies — and beyond, Toury (2012) asserts that pairing translation and norms has nothing revolutionary about it, and that Levý as the forefather of the norms was preceding this practice from his point of standing (61). Yet, even if Levý was a pioneer of norms, it was Toury who constructed an interwoven, fully descriptive approach. Therefore, before comparing the two approaches through the concepts of norms and illusion, it is beyond question that due credit should be given to definite descriptivism.

Starting with norms, Toury acknowledges two propositions about the nature in which norms operate. Firstly, for the purposes of an empirical analysis, norms are discovered through pairings on the surface structure of a translated work. Secondly, in a complex normgoverned domain such as translation, there can be alternative and competing sets of norms (Toury 2012, 76). Studying translation decisions as part of the larger background of any human behavior, Toury expounds on three types of superordinate norms within a targetoriented version of descriptive translation studies. As the highest-level decision, the initial norm is given the logical priority for explaining the "overall choice between two extreme orientations." To put it briefly, the "initial norm" is determined by a general analysis which 'values' the translator's stance in the face of constraints whether to heavily lean on the assumed original (i.e., favor adequacy) or adhere to the norms of the target culture (i.e., produce a text that falls on the acceptable end of the spectrum). However, Toury takes notice of the precarious nature of the initial norm when he suggests that "one should take care not to read too much into the initiality of the initial norm" (80). In addition, even though it is the 
transLogos 2019 Vol 2 Issue 2

Sayın, Ayşe Betül, pp. 180-203

"Illusion" in the Postcolonial Context:

Translation Studies Still in Need of a

trans Dogos

A Translation Studies Journal

Metalanguage or the Understated Lack of

Ontology of Science

(c) Diye Global Communications diye.com.tr|diye@diye.com.tr

foremost macro-level decision, it is absolutely not necessary to assume every micro-level decision to be "in full accord with one and the same initial norm" (81).

Following the initial norm comes two larger groups of norms, which work in connection with each other: "preliminary norms" and "operational norms." "Preliminary norms" comprise considerations in terms of a "translation policy," if it genuinely exists and the factual realization of it, and "directness of translation," which is useful for determining "the threshold of tolerance for translating from languages other than the ultimate SLs" (Toury 2012, 82). "Operational norms," on the other hand, are handled during the act of translation itself and demonstrated in the "so-called matricial norms" and "textual-linguistic norms." Matricial norms regulate decisions regarding the replacement of the source text material, answering whether the text is fully translated and manifesting the location of this replacement and its segmentation into chapters, stanzas, etc. (82-83). "Textual-linguistic norms," however, determine the selection of linguistic material for the generation of the target text in a more general sense, for instance in the case of a specific text type or mode of translation. Toury stresses that norms do not always have clear-cut boundaries, and they mutually influence and even two-way condition smaller considerations. Yet, apparently, preliminary norms have "both logical and temporal priority over the operational ones" (83; italics in the original). For the formulation of an explanatory hypothesis, a researcher can surely observe that these two sub-level groups of norms "intersect" under what was established to be the initial norm (84; italics in the original). Overall, how Toury conceived norms on the surface level of translation for an empirical comparative analysis based on the coupled pair seems to bear little resemblance to Levý's theorizing on norms. In fact, Levý's norms are surprisingly quite contradictory to Toury's in terms of the nature of their description. Levý devises the concept of reproduction and artistic norm for judging a work of translation according to the criteria for aesthetically pleasing works that are also appropriate to the target system, whereas Toury's classification offers tools for analysis for "a systematic scientific sub-discipline" (1982, 24; italics in the original). As a consequence, it is not surprising that aesthetics are dropped, and the notion of illusion is abandoned in Toury's theorizing. Norms in descriptive translation studies are based on the manifest material of translation and the matrix of the translated work rather than an abstract beauty reflecting the source. 
transLogos 2019 Vol 2 Issue 2

Sayın, Ayşe Betül, pp. 180-203

"Illusion" in the Postcolonial Context:

Translation Studies Still in Need of a

trans Dogos

A Translation Studies Journal

Metalanguage or the Understated Lack of

Ontology of Science

(c) Diye Global Communications diye.com.tr|diye@diye.com.tr

At a higher level, this differentiation has to do with the concept of translation. For Toury, "the actual subject matter of DTS consists first and foremost the functional-relational concepts (rather than their surface textual-linguistic representations)" (1982, 27; italics in the original). A consequence of functional-relational concepts is the translational phenomena presenting themselves as the coupled pair of a problem with a solution. Therefore, whatever type of translational relationship is obtained in studying translations, the key concept is the "invariant under transformation" (35). In order to reveal the nature of this invariant, "a hierarchy of relationships, in terms of diminishing centrality and growing peripherality should be established for every such unit" (36; italics in the original) of pair called translational equivalence. Toury suggests that translational equivalence, though carrying a very familiar name, refers to a distinct relationship in contrast to its historic counterparts, distinguishes between what is assumed to be a translation and non-translation "under certain socio-cultural circumstances" (26). So far, the comparative analysis of studies on translation focusing on the concepts of illusion and norms has highlighted a fundamental shift in the scientific approach to the subject matter. As a final point, it can be argued that ruling out of illusion from descriptive studies originates from the differentiation between theoretical and empirical approaches to science of translation. However, the revival of the concept marks another shift for translation studies.

\section{Illusion as a "Pragmatically Necessary" Metaphor for Translation}

The revival of the metaphor of illusion took place in 1988 with the publication of Mary Snell-Hornby's Translation Studies: An Integrated Approach. The metaphor itself fired up criticism from a number of scholars, particularly from Anthony Pym, and it was discussed within the wider framework of various "frameworks of equivalence" (Koller 1995, 197; italics in the original). Underlining the difference in meanings of the German term 'Äquivalenz' and its English counterpart 'equivalence,' Snell-Hornby suggests a cunning usage of the term "illusion of equivalence":

To my knowledge no translation theorist has ever doubted that Äquivalenz and equivalence are perfectly symmetrical renderings of a common interlingual tertium comparationis. In fact the opposite is true: on closer investigation subtle but crucial differences emerge between the two terms, so that they should rather be considered as 
transLogos 2019 Vol 2 Issue 2

Sayın, Ayşe Betül, pp. 180-203

"Illusion" in the Postcolonial Context:

Translation Studies Still in Need of a

trans Dogos

A Translation Studies Journal

Metalanguage or the Understated Lack of

Ontology of Science

(C) Diye Global Communications diye.com.tr|diye@diye.com.tr

warning examples of the treacherous illusion of equivalence that typifies interlingual relationships ([1988] 1995, 16-17; italics in the original).

Apparently, Snell-Hornby's understanding of what illusion in translation studies entails is about the terms of the scientific field. Her attempt to integrate divergent approaches to translation including clearly prescriptive and functionalist ones rests on a shaky basis regarding what the concept of translation denotes since she disregards the notion of invariant under transformation. Yet, this attempt in pursuit of an objective study was harshly criticized by Pym (1995). Referring to Pierre Bourdieu's (1980) statement that “illusions are not in themselves illusory" (quoted in Pym 1995, 165) but have a social system working behind them, Pym argues for "the creation of a pragmatically necessary illusion" (quoted in Hermans 2009, 98). This illusion serves the purpose of resisting "objectifying the subjective" substance of theorizing and takes notice of the sociology of translation (Pym 1995, 167). According to Pym, this argument for the search for the objective subject matter recuperates the definite idea from the 1970s: "Translation and non-translation are conventionally distinguished." Pym also expresses that arguing against a metaphor of illusion but at the same time using the term simply works as a camouflage for avoiding the taboo word of equivalence (168).

This brings us to what Werner Koller discusses in his article titled "The Concept of Equivalence and the Object of Translation Studies." In order to determine the criterion for the categorization of the approaches to translation research, Koller rightly asks:

For the subject of translation research the question of how the object is to be determined is put most succinctly by asking what preconditions must be satisfied for a text to be classified as a translation and to qualify as the object of translation studies? $(1995,195)$

As a final point, it is not unexpected to read Venuti's take on the nature of the science of translation as he again reintroduces the concept of illusionism in his ambitious history of the invisibility through "insidious domestication of foreign texts" by fluent translating (Venuti 2004, 17). Since he disregards the empirical descriptivism, the metaphor does not pose a problem at all. In his own words, "[r] esearch into translation can never be simply descriptive" (312), which he considers to be "devoid of cultural and political interests" (313). Not only the main questioning behind illusion in translation studies reveals an undeclared legitimation crisis of the field, but also the very metaphors to view the object of study as "a transparent 
transLogos 2019 Vol 2 Issue 2

Sayın, Ayşe Betül, pp. 180-203

"Illusion" in the Postcolonial Context:

Translation Studies Still in Need of a

trans Dogos

A Translation Studies Journal

Metalanguage or the Understated Lack of

Ontology of Science

(c) Diye Global Communications diye.com.tr|diye@diye.com.tr

pane of glass, a simulacrum, a replica" are ipso facto outcomes of the urgent need for a critical ontological inquiry (Hermans 2009, 98). Even if what constitutes the object of study has been discussed for a long time now, the establishment of an object "sharing one set of goals" (Toury 2012,27) on the discourse of not merely theory but also the practice with all its pragmatic and political power remains inconspicuously contradictory. Discourse of producers and consumers of translation, publishers and readers in the context of this study still repeats "the common illusions" (Pym 2008) related to the age-old deterministic categories, specifically those associated with equivalence, which manage to work through the discourse of transparency. What and how a conceptual deterministic category such as illusion corresponds to "functional operability" of "assumed translation" (Toury 2012, 28; italics in the original) can reveal more than one layer of colonial hegemonic discourse surfacing on the paratexts of the present study. Because the three postulates (i.e., source-text, transfer and relationship postulates) (Toury 2012, 28) cover the raison d'être of the very naming of a category of translation as illusionistic more comprehensively, the pragmatically necessary metaphors of both illusion and equivalence are no longer necessary. Delimiting the subject matter of the invariant under transformation but also enlarging it to encompass pseudotranslations and fictitious translations removes the metaphorical veil and thus, makes the concept of 'illusion' redundant. Translation no longer requires Alice's distorting mirror for self-definition.

\section{Grace Ellison's An Englishwoman in a Turkish Harem Travelling to and fro in} Antithetical Interpretations of Nationalism

How the pre-descriptive notion of translation materializes in practice is particularly relevant in case of back translations of postcolonial and marginalized works for they return the image of the interpellated ${ }^{5}$ abroad to its 'home' audience. What norms reveal for the discourse of the practice of back translation in a cultural setting provides grounds for analyzing the relationship between illusion and equivalence on a meta-level. Ironically

\footnotetext{
${ }^{5}$ Here interpellation in the sense of Louis Althusser's theory of ideology can be conveniently applied to the present case study. Also, it should be noted that studying translations of semi-ethnographic travelogues as works of postcolonial translation should not indicate that Ottoman state is considered an official colony of the British Empire. I think about the translation in question as a work fully displaying the system of hegemonic power relations in which marginalized works are positioned. For an analysis on the notion of 'hegemony' in postcolonial translation theory, see Robinson 2014, 22.
} 
transLogos 2019 Vol 2 Issue 2

Sayın, Ayşe Betül, pp. 180-203

"Illusion" in the Postcolonial Context:

Translation Studies Still in Need of a

trans Dogos

A Translation Studies Journal

Metalanguage or the Understated Lack of

Ontology of Science

(C) Diye Global Communications diye.com.tr|diye@diye.com.tr

enough, a descriptive study on the paratexts of translation of the equivocal author Grace Ellison's An Englishwoman in a Turkish Harem delivers a contradicting point of view.

Before going into details of the text itself, author's reception as an author-journalist needs to be contextualized. Unsurprisingly, Ellison caught fair attention from the critics after the publication of Turkish translations of her blandly titled An Englishwoman in Angora ${ }^{6}$ (1923) in 1999. Numerous critics allude to her as "a Kemalist" (Hekimoğlu 1999; Günbaş 2000; Armstrong n.d.), but her unwavering English nationalism led French readers to call her “a militant journalist” (Quella-Villéger 2014). Though her patriotic discussion on the rightful hostility of the British towards the French influence on the Ottomans during World War I is quite visible, her own life story still remains in the dark. An ardent supporter of İttihat ve Terakki Fırkası (The Committee of Union and Progress [CUP]), she was keen to turn a blind eye to the 'atrocities' committed at the time. More than a decade after her visit to Istanbul, she returned en route to Ankara aiming to interview Mustafa Kemal and wrote at least two other books, namely An Englishwoman in Angora (1923) mentioned above and Turkey To-day (1928). In these later works, she certainly expresses her support for the newly founded Turkish state.

Coming to the source text, the articles that comprise the book itself appeared in The Daily Telegraph in 1914 between January 24 and February 6. As soon as the articles started to be published in London, they were translated into Turkish, and the translations appeared in Tanin, the official newspaper of the CUP, formerly owned by one of the prominent and controversial figures of the literary and political circles of the time, Hüseyin Cahid. Several days before the translation appeared, Tanin was seized by force by the Committee after being pressurized to put an end to the criticisms the paper voiced (Koyuncu 1993). This series titled "Bir İngiliz Edibesi Nazarında Türkiye ve Türkiye Kadınları” (Turkey and Turkish women in the eyes of an English authoress) were published between February 4 and March 7. The prologue gives clues regarding the initial norm of the translation:

Şimdi İngiliz muhibbemiz buradan topladığı hatırat ve hissiyatı (Daily Telegraph) da neşretmeye başlamıştır. "Harem Hayatı" unvanıyla çıkan bu silsile-i makalat hayat-1 umumiyede tesir-i mutlak ve muhakkak olan hususiyetimize nafiz bir bakış demektir.

\footnotetext{
${ }^{6}$ This work was previously translated into Turkish by İbrahim S. Turek and Osman Olcay and was published in 1973 and 1999 respectively. The translation published in 2007 seems to be plagiarized from the translation dated 1973. See fig. 3, 4 and 5.
} 
transLogos 2019 Vol 2 Issue 2

Sayın, Ayşe Betül, pp. 180-203

"Illusion" in the Postcolonial Context:

Translation Studies Still in Need of a

trans Dogos

A Translation Studies Journal

Metalanguage or the Understated Lack of

Ontology of Science

(C) Diye Global Communications diye.com.tr|diye@diye.com.tr

Onda serbest, intizam-cû bir İngiliz kadınının ihtimal ki bir darbe-i nüvâz-şikâr ile ihtar ettiği kusurlarda yazılacak; binaenaleyh böyle sahib-i şöhret ve maahazâ o şöhrete bihakkın sahip bir İngiliz edibesinin memleketimize ve memleketimizin mahremiyetine dair yazdıklarının aksam-1 mühimmesini tercüme ve nakil vazifesini deruhte ediyoruz. Karie ve karilerimizin bunları büyük bir lezzetle takip edeceklerinden eminiz. ${ }^{7}$

(Now our English authoress has started to publish her memoirs and impressions that she collected from here. This series of articles titled "Life in Harem" is an intimate look at our character which is certainly effective in public life. This view will express the flaws a free well-ordered English woman warns us against, and hence, we assume the duty to translate and transfer a rightly renowned English authoress' writing on our country and the intimate issues of our country. Surely our readeress and readers will follow these articles with great pleasure. $)^{8}$

In the following year, in 1915 the book titled An Englishwoman in a Turkish Harem appeared as a rewriting by Ellison of the articles with additions specifically conveying the Orientalist descriptions of "inexplicable sadness" and the last four chapters of the book as well as omissions of passages directly commenting on the political situation. Yet, this time it almost took a century for the book to be translated into Turkish, as the translation entitled İstanbul'da Bir Konak ve Yeni Kadınlar: İngiliz Kadın Gazetecinin Gözüyle Türk Evi ve Gündelik Hayat (A mansion in Istanbul and new women: Turkish home and daily life in the eyes of a British woman journalist) was published in 2009.

The comparative analysis on the paratexts of the source text and the target text is summarized in table 1 below. However, before analyzing the paratexts in detail, I would like to point to the varying interpretations of Ellison's work and her identity as the author depicted in the covers of her previously translated work. She is the blonde frowning femme fatale in a desolate village with a shepherd and his herd and the old parliament building in Ankara behind her illustrated in comics style, later to become the smiling lady with wavering hair accompanied by photographs of a proudly standing palatial building of a European city, old parliament building in Ankara, a village in ruins and the view from the presidential estate in Çankaya in the background. Presenting a politically motivated case, the most recent edition of the translation of An Englishwoman in Angora appeared without any description whatsoever apart from her name stated next to the contentious figure of Dr. Riza Nur on top of a

\footnotetext{
${ }^{7}$ I would like to thank Hazal Bozyer and Esra Bal for transcribing this passage into Latin letters. See fig. 2.

${ }^{8}$ Translations are mine unless otherwise stated.
} 
transLogos 2019 Vol 2 Issue 2

Sayın, Ayşe Betül, pp. 180-203

"Illusion" in the Postcolonial Context:

Translation Studies Still in Need of a

photograph of Mustafa Kemal saluting the people from the balcony of the old parliament. Thus, the selection criteria of this certain work for translation and hence the preliminary norm seem to be related to the disputed relationships and motivations with regards to the political figures of the period, who are highly capitalized in the market.

Table 1. A comparative analysis on the paratexts of the ST and the TT

\begin{tabular}{|c|c|c|}
\hline & $\begin{array}{l}\text { An Englishwoman in a Turkish } \\
\text { Harem }^{9}\end{array}$ & 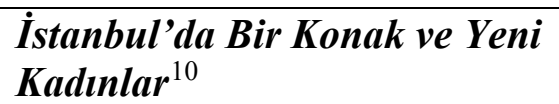 \\
\hline Cover page & $\begin{array}{l}\text { The cover states the author's } \\
\text { name and announces the } \\
\text { introduction is by renowned } \\
\text { Orientalist Edward G. Browne. } \\
\text { Inside cover page has the titles } \\
\text { of other works "by the same } \\
\text { author," namely Abdul Hamid's } \\
\text { Daughter and A Turkish } \\
\text { Woman's European } \\
\text { Impressions. }\end{array}$ & $\begin{array}{l}\text { The cover page has a painting } \\
\text { titled "A Harem Scene" by Blas } \\
\text { Olleras y Quintana. Inside cover } \\
\text { page states the name of the } \\
\text { author on top, with the title of } \\
\text { the book and the translator Neşe } \\
\text { Akın's name respectively. }\end{array}$ \\
\hline Frontispiece & $\begin{array}{l}\text { Author's portrait with the } \\
\text { caption "in Turkish costume" }\end{array}$ & $\begin{array}{l}\text { Author's portrait without a } \\
\text { caption }\end{array}$ \\
\hline Introduction & By Edward G. Browne & No introduction \\
\hline Illustrations & $\begin{array}{l}12 \text { illustrations plus the } \\
\text { frontispiece }\end{array}$ & No illustrations \\
\hline Dedication & $\begin{array}{l}\text { States "I dedicate these letters to } \\
\text { all those who made my visit so } \\
\text { interesting and happy, but } \\
\text { particularly my friend and } \\
\text { hostess," i.e., the character } \\
\text { Fatma. }\end{array}$ & $\begin{array}{l}\text { States "Bu mektupları, } \\
\text { ziyaretimi ziyadesiyle ilginç ve } \\
\text { mutlu kılan herkese, ancak } \\
\text { özellikle ev sahibem olan } \\
\text { dostuma ithaf ediyorum. G. } \\
\text { Ellison" }\end{array}$ \\
\hline Preface & Written by Ellison & Written by Ellison \\
\hline Series & $\begin{array}{l}\text { Other titles by the publisher } \\
\text { include Rubaiyat of Omer } \\
\text { Hayyam translated by Edward } \\
\text { Fitzgerald. }\end{array}$ & $\begin{array}{l}\text { "Batının Gözüyle Türkler" } \\
\text { (Turks in the eyes of the West) }\end{array}$ \\
\hline Number of footnotes & 3 & 20 \\
\hline
\end{tabular}

Starting the analysis with the title of the book, the curious change in the name which literally translates into English as "a mansion in Istanbul and new women: Turkish home and daily life in the eyes of a British woman journalist" reflects the translation policy of the

\footnotetext{
${ }^{9}$ See fig. 1 in the appendices.

${ }^{10}$ See fig. 6 .
} 
transLogos 2019 Vol 2 Issue 2

Sayın, Ayşe Betül, pp. 180-203

"Illusion" in the Postcolonial Context:

Translation Studies Still in Need of a

trans Dogos

A Translation Studies Journal

Metalanguage or the Understated Lack of

Ontology of Science

(c) Diye Global Communications diye.com.tr|diye@diye.com.tr

publisher. While probably the most illustrious signature concept of the letters turned into book is abandoned, the subheading stresses the identity of the author. In the following page, the preface ${ }^{11}$ signed by the name of the publisher (i.e., Dergâh) very clearly explains the matricial norms that the publisher aimed to prioritize for the translation. However, first how the book came to be written by Ellison is briefly told. The reader is informed on the British feminist journalist, that the author had penned two other works titled Abdülhamit's Daughter" and A Turkish Woman's European Impressions during "the period of autocracy" and that these works had already been translated into Turkish (Ellison [2009] 2017, 5). However, the very first work the author wrote without collaborating with someone else is published for the first time in Turkish. In the following lines, the major translation strategy is revealed as the editor expresses how the decision was taken for abandoning and foregrounding of the concept of harem throughout the work, as it is stated:

Eserin başlığında geçen harem kelimesi ne Batılıların anladığı malum mânayı ne de Türkçede kullanıldığı anlamda Osmanlı sarayında padişahın aile efradının yaşadığı bölümü ifade ediyor . . . Yazar her seferinde bu konak için 1srarla harem kelimesini kullanıyor. Türkçede harem'in ev mânasına kullanıldığ 1 da malumdur. Bu nedenle tercümenin bazı yerlerinde, metnin gidişine göre ev kelimesi kullanılmış; bazı yerlerinde ise harem kelimesi italik harflerle verilmiştir. (Ellison [2009] 2017, 6)

(The word harem in the title of the work expresses neither the certain meaning as the Westerners understand it nor the meaning it has in Turkish for the certain part of the palace where the household of the sultan dwells ... The author uses the word harem each and every time for this mansion insistently. It is known that the word harem has the meaning of home in Turkish. For this reason, in some parts of the translation the word for home is used if it suits the context, whereas in some other parts it is translated as harem in italics. $)^{13}$

In addition to pointing out that Ellison had an interview with Mustafa Kemal, the preface evidently puts that Ellison was not able to break free from English empiricism and overall pursuing what is obtusely observed. Also, the preface goes even further and underlines the ideology behind the naming of the series by declaring "just like all the Westerners, she is cursing Sultan Abdulhamid and praises Sultan Reşad to whose presence she was admitted."

\footnotetext{
${ }^{11}$ After contacting the publishing house, I learnt that the preface was written by the series editor Iş1l Erverdi.

${ }^{12}$ It is interesting why the editor chose to write the name of the Sultan in Turkish spelling.

${ }^{13}$ All the translations of passages from the preface are quoted from Sayin 2019b. Also for a descriptive analysis on the paratexts of A Turkish Woman's European Impressions, see Sayın 2019a.
} 
transLogos 2019 Vol 2 Issue 2

Sayın, Ayşe Betül, pp. 180-203

"Illusion" in the Postcolonial Context:

Translation Studies Still in Need of a

trans(Dogos

A Translation Studies Journal

Metalanguage or the Understated Lack of

Ontology of Science

(C) Diye Global Communications diye.com.tr|diye@diye.com.tr

Finally, how the publisher intends the book to be received in the Turkish system is made clear in the last paragraph of the preface:

İngiliz kamuoyunda Türk dostu olarak tanınmasına ve belli düzeyde romantik bir içtenlik taşımasına rağmen, Grace Ellison, Doğu'ya ve Osmanlı'ya bakan her Batılının taşıdığı birtakım cehaleti, yanlış anlamayı ve dönüştürücü anlayışı bertaraf edemiyor. Batının Gözüyle Türkler serisinde... (Ellison [2009] 2017, 6)

(Though recognized as a Turcophile in British public opinion and carrying a certain level of romantic sincerity, Grace Ellison is unable to eliminate the ignorance, misunderstanding and manipulative approach that every Westerner encountering the East and the Ottomans delivers. From the Turks in the Eyes of the West series...)

The critical remark by the editor on Ellison's work is clearly judgmental, and yet, how it reflects on translation serves illusory purposes. For instance, as the title of the series, "Batının Gözüyle Türkler" implies, the translation painfully strives to be adequate according to Toury's classification. However, the voice of narration denies the reader the univocality expected from the tone of the preface. This uncertainty, which is surely a common feature of postcolonial translations, is visible in the footnotes as well. There are only 3 footnotes in the source text but 20 in the translated work. 15 of these footnotes are authored by the translator, and one of them is significant in reading the inevitable multiple layers of voice. In this particular footnote, the translator intervenes to distinguish between the original poem by Mihri Hatun, Ellison's translation of Mihri Hatun's verses in the source text and her own work (Ellison [2009] 2017, 90).

Therefore, the claim for total faithfulness to the source text that in turn conveys the representation of the "Turks in the eyes of the West" creates a paradox that denies the existence of multiple layers of interpretation surrounding the translation. The positioning of the work within the series reinforces the understanding behind the initial norm as the website of the publisher announces that this series ${ }^{14}$ is designed to include three sub-categories: memories, reports, letters and biographies of American missionaries; journals and travel accounts of the ambassadors about politics and palace; the romantic texts about Istanbul and daily life mostly written by women writers. The publisher also clarifies its perspective for this

\footnotetext{
${ }^{14}$ Nilüfer Alimen analyzes this series with a descriptive point of view in detail. See Alimen 2019. Also, for Muhammed Baydere's analysis of translations of Dorina L. Neave's Twenty-six Years on the Bosphorus within the same series in the context of the translator's voice in textless back translations, see Baydere 2018a and $2018 b$.
} 
transLogos 2019 Vol 2 Issue 2

Sayın, Ayşe Betül, pp. 180-203

"Illusion" in the Postcolonial Context:

Translation Studies Still in Need of a

trans Dogos

A Translation Studies Journal

Metalanguage or the Understated Lack of

Ontology of Science

(c) Diye Global Communications diye.com.tr|diye@diye.com.tr

series as the statement points that they did not put any limitations whatsoever on authors' professions, languages and their views of Turks and that they publish the works "as they are" without any change or 'manipulation.' It is also suggested that the purpose of this series rests on this "variety." 15

Nonetheless the argument for opaquely transferring the content of a work refutes itself in practice. The translation illusion that shatters in the preface strives to restructure in the footnotes without success time after time since translations of postcolonial works are subject to two layers of transference as opposed to any other translation. The inherent peculiarity of "translation of "translation"” (Baer 2014, 241) forces the paradoxical double bind to first unfold and close on itself, transferring the polyphonous reading of the culturally-translated text back to its original source. No matter how hard a work tries to be ingenuous to its source, the ambivalent nature of the foreign and native takes hold of the reception of a work as the translation as part of a target system triumphs the most determined resistance against manipulation. The "native will to be master" regulates its mimesis through a transparent process of anti-illusionism (Tageldin 2011 quoted in Baer 2014, 236).

\section{Conclusion}

The interchanging concepts of illusion and equivalence are manifested in the metalanguage trap theory on postcolonial translations is very frequently lured into. By overlooking the fact that "the ship of Theseus must be redesigned, reengineered and rebuilt" (Tymoczko 2014, 283) each time the process of translation takes place, prescriptive designations for theorizing on translation such as illusionism reemerge in the discourse of translation paratexts explicitly protesting the normative binaries of hegemonic representation. Hence, the way in which translation as an ontological concept can overcome the reflexive pitfall seems to lie somewhere beyond the conceptual determinism of pre-descriptive paradigms. The initial decision to back translate the representation of the 'Turks' completely adequately foregrounds not only the shattering illusion in the title, preface and the creation of a series, but also how the deterministic conceptions of translation end up refuting the

\footnotetext{
${ }^{15}$ Dergâh’s page for “Batının Gözüyle Türkler," accessed July 5, 2019, http://www.dergah.com.tr/kitap/batiningozuyle-turkler.
} 
transLogos 2019 Vol 2 Issue 2

Sayın, Ayşe Betül, pp. 180-203

"Illusion" in the Postcolonial Context:

Translation Studies Still in Need of a

trans Dogos

A Translation Studies Journal

Metalanguage or the Understated Lack of

Ontology of Science

(c) Diye Global Communications diye.com.tr|diye@diye.com.tr

predestined 'existential' purpose of translations. ${ }^{16}$ In this respect, the present descriptive analysis on the paratextual material reveals that the main problem underlying postcolonial translations is a lack of theorizing not on an ontology of translation, but on ontology of translation studies as a discipline providing an intellectual space where descriptive indeterminist theories of translation reflect onto the practice itself.

In case of methodology of inquiry, this study commenced with the question Hermans (2009) asks whether "we [should] adopt a semasiological or an onomasiological principle" (101). After a brief survey of theory on illusionism in translation, I argue that such a distinction does not matter because the surface textual structure is inescapably the outcome of the underlying concept of translation. Thus, it is crystal-clear that the central object of the field converges the split roads into one under the ontology of translation studies. In light of the translated work in the corpus of this study, the publisher's preface reflects "traditional metaphysical thinking" in Edwin Gentzler's $(2001,147)$ words. Yet, considering that the historical existence of translation and related rewriting practices in the Ottoman context originated from the need to know what the European 'Other' thought of Ottomans even before the Tanzimat period, the norms shaping a seemingly opposite translation strategy present an intriguing case both for ontology and temporality of what the concept 'translation' holds true for the Turkish polysystem.

Holmes (1985), the inspirational pioneer of translation studies, expresses that "translators are also human beings, despite all their efforts to function as clear-glass windows which the bright sun of the author's text can shine through undistorted" (quoted in Gentzler 1990, 274). The assumption on distortion requires an original that cannot avoid being "not absolutely self-identical” (Benjamin 2014, 172). Hence, with each new interpretation and systemic positioning, the questioning of the concept renews itself and demands asking "how the relationship between interpretation and object of interpretation, and translation and original [is] to be understood" (162).

At the apexes of theory and practice, this paper calls for a future discussion on a heuristic model, initially developed by Toury and broadened without losing its connection with the central descriptive concept of translation. The attempt to establish new categories and

\footnotetext{
${ }^{16}$ For Toury's explanation of "the 'act' part of the 'event"' on how norms govern the translated work, see Toury $2012,68$.
} 
transLogos 2019 Vol 2 Issue 2

Sayın, Ayşe Betül, pp. 180-203

"Illusion" in the Postcolonial Context:

Translation Studies Still in Need of a

trans Dogos

A Translation Studies Journal

Metalanguage or the Understated Lack of

Ontology of Science

(C) Diye Global Communications diye.com.tr|diye@diye.com.tr

interpretations of translation by unsettling the foundations of descriptivism of the discipline through captious arguments and creating pseudoproblems ends up merely limiting progressive thinking for translation studies. ${ }^{17}$ It also lays bare that research in translation studies is not necessarily founded on accurate mastery of the ontology and epistemology of a social science. And if we are discussing the metaphysicality of theories of translation, we should be tracing the steps of philosophical thinking through ages. And such a discussion would not necessitate a metaphor of equivalence as basis of theorizing, but restructuring the boundaries of scientific object analyzed. Thus, the question to ask on the metalevel would be: how does the invariant under transformation translate into the very being of translation in a post-positivistic perspective on the science of translation?

\footnotetext{
${ }^{17}$ For a thought-provoking inquiry on pseudoproblems of translation studies, see Güneş 2019.
} 
transLogos 2019 Vol 2 Issue 2

Sayın, Ayşe Betül, pp. 180-203

"Illusion" in the Postcolonial Context:

transDogos

Translation Studies Still in Need of a

A Translation Studies Journal

Metalanguage or the Understated Lack of

Ontology of Science

(C) Diye Global Communications diye.com.tr|diye@diye.com.tr

\section{Appendices}

Figure 1. Front cover of Grace Ellison's book published in 1915

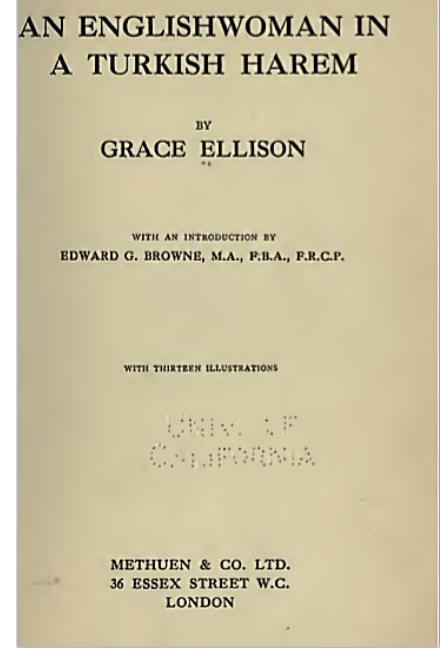

Figure 2. The prologue to serialized translation of articles published in Tanin dated February 4,1914

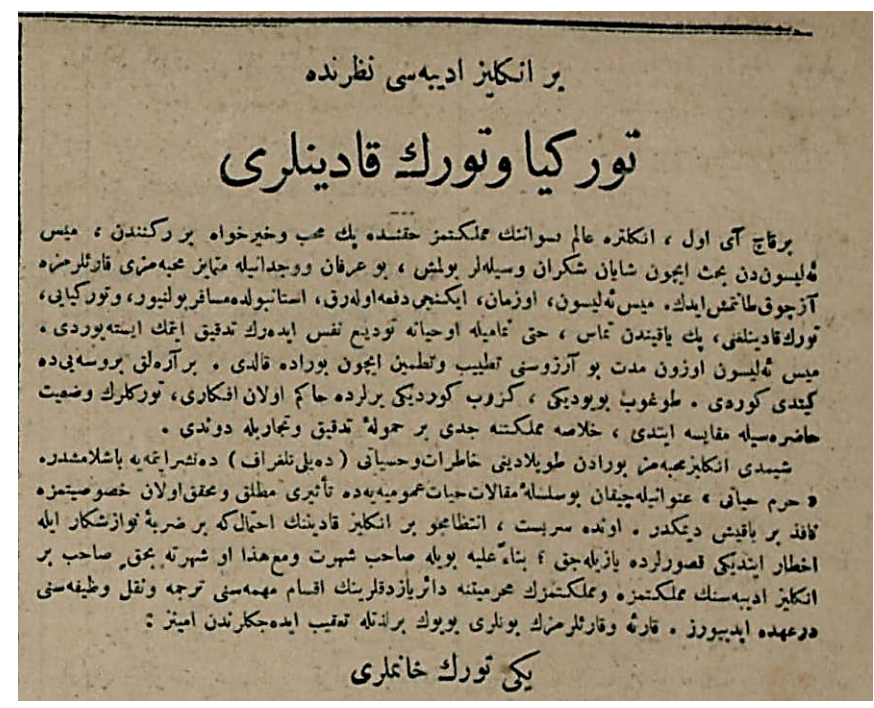


transLogos 2019 Vol 2 Issue 2

Sayın, Ayşe Betül, pp. 180-203

"Illusion" in the Postcolonial Context:

trans Dogos

A Translation Studies Journal

Translation Studies Still in Need of a

Metalanguage or the Understated Lack of

Ontology of Science

(C) Diye Global Communications diye.com.tr|diye@diye.com.tr

Figure 3. Front and back covers of Bir Ingiliz Kadını Gözüyle Kuva-i Millîye Ankarası (translated by İbrahim S. Turek), 1973
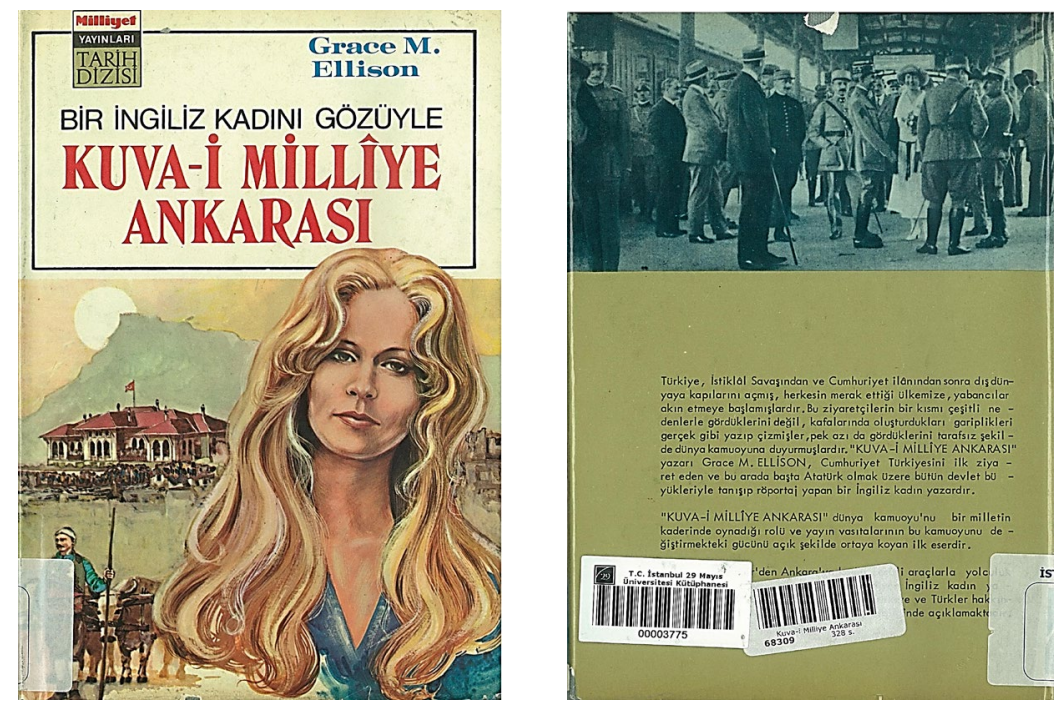

Figure 4. Front and back covers of Ankara'da Bir Ingiliz Kadını (translated by Osman Olcay), 1999
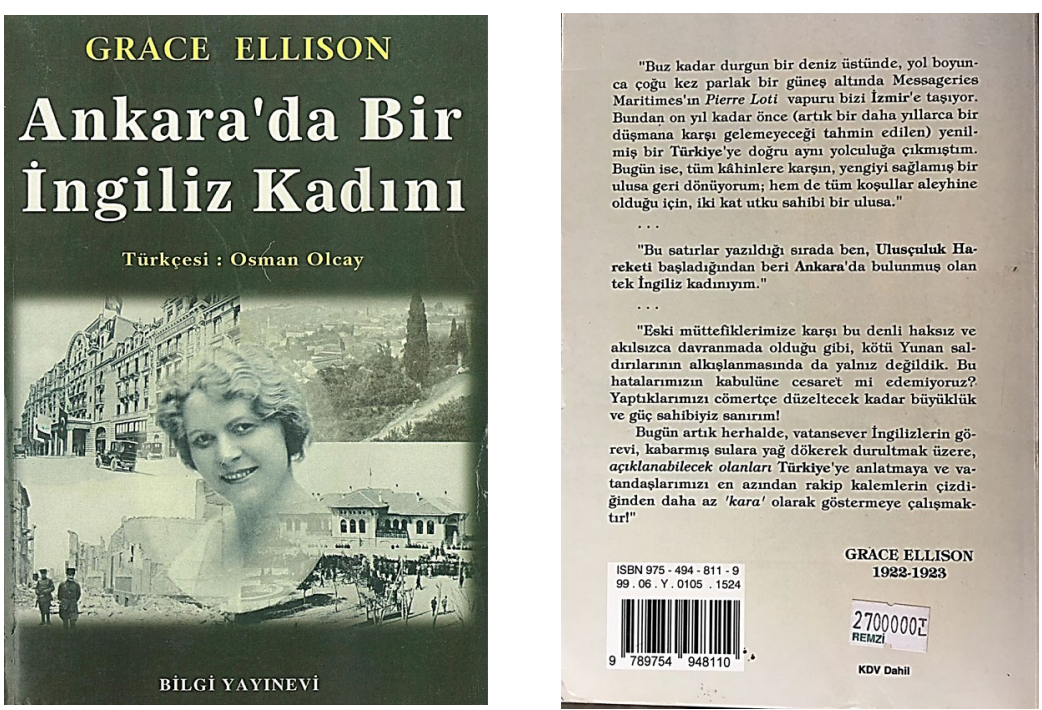
transLogos 2019 Vol 2 Issue 2

Sayın, Ayşe Betül, pp. 180-203

"Illusion" in the Postcolonial Context:

trans Dogos

Translation Studies Still in Need of a

A Translation Studies Journa

Metalanguage or the Understated Lack of

Ontology of Science

(C) Diye Global Communications diye.com.tr|diye@diye.com.tr

Figure 5. Front and back covers of İlk Meclisin Perde Arkast (1920-1923), 2007 incorporating Ankara'da Bir İngiliz Kadını (translated by Ö. Andaç Uğurlu)
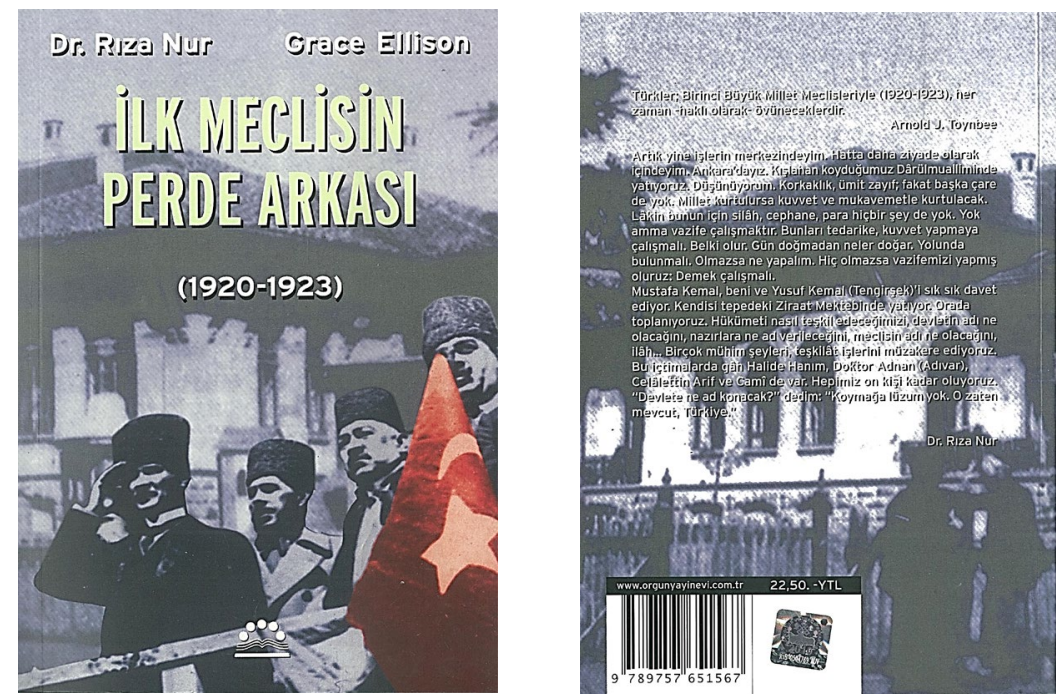

Figure 6. 2009 and 2017 front covers of İstanbul'da Bir Konak ve Yeni Kadınlar: Ingiliz Kadın Gazetecinin Gözüyle Türk Evi ve Gündelik Hayat (translated by Neşe Akın)
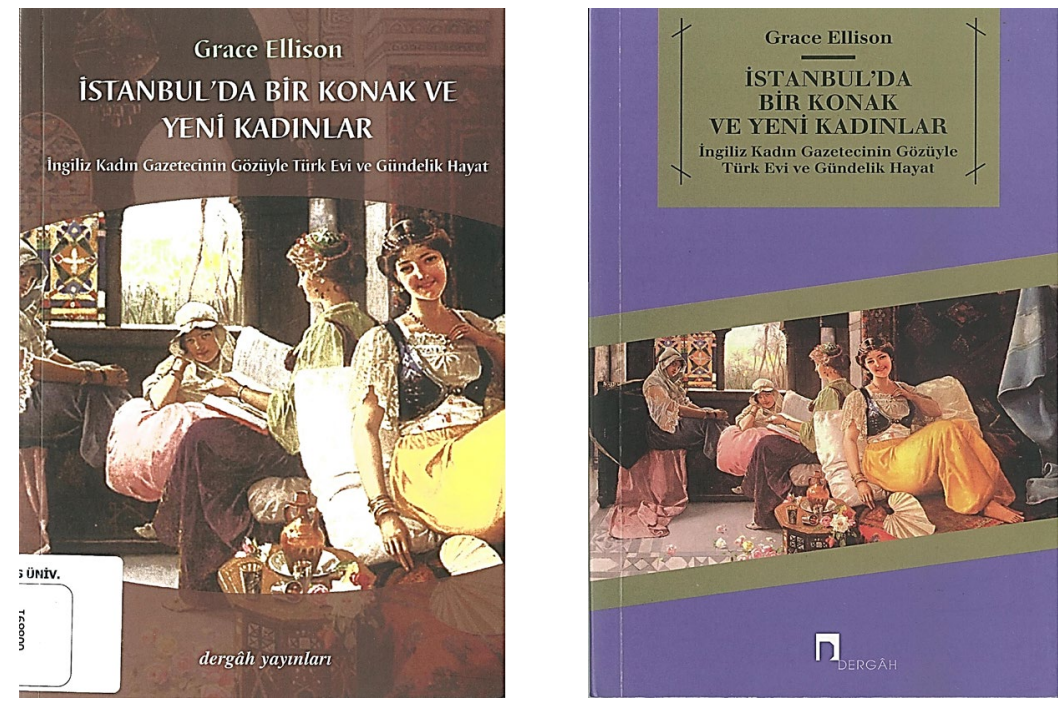
transLogos 2019 Vol 2 Issue 2

Sayın, Ayşe Betül, pp. 180-203

"Illusion" in the Postcolonial Context:

Translation Studies Still in Need of a

trans Dogos

A Translation Studies Journal

Metalanguage or the Understated Lack of

Ontology of Science

(c) Diye Global Communications diye.com.tr|diye@diye.com.tr

\section{References}

Alimen, Nilüfer. 2019. “Batı'nın Doğu Çevirisi Olarak Oryantalizm ve Oryantalist Metinlerin Türkçeye Çevirileri." [Orientalism as the West's translation of the East and translation of Orientalist texts into Turkish.] In Çeviribilimde Araştırmalar [Research in Translation Studies], edited by Seda Taş, 59-92. Istanbul: Hiperyayın.

Armstrong, William. n.d. “An English Kemalist in Anatolia, 1922.” Hürriyet Daily News. Accessed July 5, 2019. http://www.hurriyetdailynews.com/opinion/williamarmstrong/an-english-kemalist-in-anatolia-1922-78850.

Baer, Ben Conisbee. 2014. "What is Special about Postcolonial Translation?" In $A$ Companion to Translation Studies, edited by Sandra Bermann and Catherine Porter, 233-245. West Sussex: Wiley Blackwell.

Baydere, Muhammed. 2018a. "Çevirmenlerin Sesinden Sultan Abdülhamit Dönemini Dinlemek: Türkçede Twenty-six Years on the Bosphorus." [Giving ear to the Abdulhamid period from the translators' voice: Twenty-six Years on the Bosphorus in Turkish.] Paper presented at the 4th Asoscongress International Symposium on Philology, Antalya, May 3-5.

. 2018b. "Geri Çevirilerde Çevirmenin İzini Sürmek." [Following the translator's trace in back translations.] In Çeviribilimde Güncel Tartışmalardan Kavramsal Sorgulamalara [From recent discussions to conceptual reflections in Translation Studies], edited by Seda Taş, 317-346. Istanbul: Hiperyayın.

Benjamin, Andrew. 2014. Translation and the Nature of Philosophy: A New Theory of Words. Oxon: Routledge.

Conway, Kyle. 2012. "A Conceptual and Empirical Approach to Cultural Translation." Translation Studies 5 (3): 264-279. doi:10.1080/14781700.2012.701938.

Ellison, Grace. 1914. “Life in the Harem.” The Daily Telegraph. January 24-February 6.

1915. An Englishwoman in a Turkish Harem. London: Methuen.

1973. Bir İngiliz Kadını Gözüyle Kuva-i Millîye Ankarast. Translated by İbrahim S.

Turek. Istanbul: Milliyet.

1999. Ankara'da Bir İngiliz Kadını. Translated by Osman Olcay. Ankara: Bilgi.

. (2009) 2017. Istanbul'da Bir Konak ve Yeni Kadınlar: Ingiliz Kadın Gazetecinin Gözüyle Türk Evi ve Gündelik Hayat [A mansion in Istanbul and new women: Turkish home and daily life in the eyes of a British woman journalist]. Translated by Neşe Akın. Istanbul: Dergâh. 
transLogos 2019 Vol 2 Issue 2

Sayın, Ayşe Betül, pp. 180-203

"Illusion" in the Postcolonial Context:

Translation Studies Still in Need of a

trans(Dogos

A Translation Studies Journal

Metalanguage or the Understated Lack of

Ontology of Science

(c) Diye Global Communications diye.com.tr|diye@diye.com.tr

Gentzler, Edwin. 1990. "Contemporary Translation Theory." PhD diss., Vanderbilt University. 2001. Contemporary Translation Theories. Clevedon: Multilingual Matters.

Günbaş, Ahmet. 2000. "Bir 'İngiliz Kadını'nın Anlattıkları.” [Things an "English woman” narrates.] Cumhuriyet Kitap, July 27.

Güneş, Alper Zafer. 2018. "Translated in Translation Studies." transLogos Translation Studies Journal 1 (1): 1-24. doi:10.29228/transLogos.1/1.6.

- 2019. "The Problem of Pseudo-problems in Translation Studies." Paper presented at the 2nd International Rumeli [Language, Literature, Translation] Symposium, Kurklareli, April 12-13.

Hekimoğlu, Müşerref. 1999. “Ankara'da Bir İngiliz Kadını.” [An English woman in Ankara.] Cumhuriyet Dergi, June 27.

Hermans, Theo. 2009. Translation in Systems: Descriptive and System-Oriented Approaches Explained. Manchester: St. Jerome.

Holmes, James S. 1988. Translated! Papers on Literary Translation and Translation Studies. Amsterdam: Rodopi.

Koller, Werner. 1995. "The Concept of Equivalence and the Object of Translation Studies." Target 7 (2): 191-222. doi:10.1075/target.7.2.02kol.

Koyuncu, Nurhan. 1993. "1908-1914 Yılları Arasında Tanin Gazetesinde Çıkan Edebî Yazıların Toplanması, Latin Harflerine Çevrilmesi ve İncelenmesi." [Collection of literary articles published in Tanin between 1908-1914, translation into Latin alphabet and analysis.] Master's thesis, Hacettepe University.

Levý, Jiří. 2011. The Art of Translation. Translated by Patrick Corness. Edited by Zuzana Jettmarová. Amsterdam: John Benjamins.

Nur, Rıza, and Grace Ellison. 2007. Ilk Meclisin Perde Arkası (1920-1923). Translated by Ö. Andaç Uğurlu. Istanbul: Örgün.

Pratt, Mary Louise, Birgit Wagner, Ovidi Carbonell i Cortés, Andrew Chesterman, and Maria Tymoczko. 2010. "Translation Studies Forum: Cultural Translation." Translation Studies 3 (1): 94-110. doi:10.1080/14781700903338706.

Pym, Anthony. 1995. "European Translation Studies, Une science qui dérange, and Why Equivalence Needn't Be a Dirty Word.” TTR 8 (1): 153-176. doi:10.7202/037200ar. 
transLogos 2019 Vol 2 Issue 2

Sayın, Ayşe Betül, pp. 180-203

"Illusion" in the Postcolonial Context:

Translation Studies Still in Need of a

—. 2008. "On Indeterminacy in Translation: A Survey of Western Theories." Unpublished manuscript. PDF File. http://usuaris.tinet.cat/apym/online/translation/2008_\%20Indeterminacy.pdf.

Quella-Villéger, Alain. 2014. Haremden Kaçanlar: Ístanbul'da Bir Devlet Meselesi ve Feminizm [Fugitives from harem: A state affair and feminism in Istanbul]. Translated by Aysel Bora. Istanbul: Yapı Kredi.

Robinson, Douglas. 2014. Translation and Empire: Postcolonial Theories Explained. London: Routledge.

Sayın, Ayşe Betül. 2019a. "Çevirinin Yuvaya Dönüşü: Sömürgecilik Sonrası Çeviri Kuramında "Metinsiz Geri Çeviriler." [The return of the native: "Textless back translations" in postcolonial Translation Studies.] In Çeviribilimde Araştırmalar [Research in Translation Studies], edited by Seda Taş, 235-250. Istanbul: Hiperyayın.

- 2019b. "Dis/Re-Appearance of Illusion: The Quest for an Ontology of Translation Studies.” Master's thesis, Istanbul 29 Mayıs University.

Snell-Hornby, Mary. (1988) 1995. Translation Studies: An Integrated Approach. Amsterdam: John Benjamins.

Sturge, Kate. 2007. Representing Others: Translation, Ethnography and the Museum. Manchester: St. Jerome.

Tanin. 1914. "Bir İngiliz Edibesi Nazarında Türkiye ve Türk Kadınları.” [Turkey and Turkish women in the eyes of an English authoress.] February 4.

Toury, Gideon. 1982. “A Rationale for Descriptive Translation Studies.” Dispositio 7 (1921): $23-39$.

- 2012. Descriptive Translation Studies — and Beyond. 2nd expanded ed. Amsterdam: John Benjamins. First published 1995.

Tymoczko, Maria. 2000. "Translations of Themselves: The Contours of Postcolonial Fiction." In Changing the Terms: Translating in the Postcolonial Era, edited by Sherry Simon and Paul St-Pierre, 147-163. Ottawa: University of Ottawa Press.

2014. Translation in a Postcolonial Context: Early Irish Literature in English Translation. London: Routledge.

Venuti, Lawrence. 2004. The Translator's Invisibility: A History of Translation. London: Routledge. 